EPiC Series in Computing
Volume 58, 2019, Pages 464-474
$\begin{gathered}\text { Proceedings of 34th International Confer- } \\ \text { ence on Computers and Their Applications }\end{gathered}$

\title{
An Empirical Examination of the Effects of IT Leadership on Information Security Risk Management in USA Organizations
}

\author{
Henry Okonofua ${ }^{1}$, Shawon S. M. Rahman ${ }^{2, *}$ and Reni Ivanova ${ }^{3}$
}

${ }^{1} \mathrm{PhD}$ Candidate, Information Technology, Capella University, 225 South 6th St, Minneapolis, MN 55402, USA hokonofua@capellauniversity.edu

${ }^{2}$ Associate Professor, Department of Computer Science and Engineering, University of HawaiiHilo, Hilo, HI 96720 sRahman@Hawai i . edu and

Part-time Faculty, Capella University, 225 South 6th St, Minneapolis, MN 55402, USA

${ }^{3}$ Professor

Department of Mathematics, University of Hawaii-Hilo, Hilo, HI 96720, USA

rivanova@hawaii.edu

\begin{abstract}
Although organizations face continuously evolving Information Security (IS) risks, the scholarly literature is unclear as to whether transformational, transactional, and passive-avoidant leadership styles influence IS risk management. The study was conducted using a quantitative, non-experimental, and descriptive research design. The sample consisted of senior IT leaders with a range of titles including Chief Information Officer (CIO), Chief Information Security Officer (CISO), Director of IT, and IT Manager. This population is characterized by extensive knowledge of IT and IS issues, and these individuals are generally responsible for directing an organization's approach to IS risk management. Data from 250 participant surveys were analyzed using the Pearson product-moment coefficient correlation and multiple regression analysis. The results of the analysis demonstrated that both IT leadership is significantly related to IS risk management.
\end{abstract}

Keywords: IT Leadership, Information Security Risk Management, IS Risk, Transactional Leadership, Transformational Leadership

${ }^{*}$ Corresponding author 


\section{Introduction}

Information security (IS) risk management has become an essential element of the best practices in corporate governance [1],[2]. IS risk management is no longer being treated as an IT issue but as a critical component of general business practice in organizations [6]. Supporting this observation, Bobbert and Mulder [10] noted that IS risk management policy is decided at the board level and implemented by information technology (IT) leadership. Recognizing the central roles of both IT leaders and IS governance, the present study examined the relationship between these factors and their influence on IS risk management in U.S.-based organizations.

Managing the risk of information security breaches is now a regular matter of concern at Board level in U.S. organizations. Von Solms and von Solms [11] acknowledged this when they noted that by the end of the first decade of the new millennium, information security risk management had become the primary concern of corporate governance. By 1998, the Information Systems Audit and Control Association (ISACA) had established the IT Governance Institute, whose 2006 guide for boards of directors and executive management noted that it was expected that boards of directors would treat information security as an intrinsic element within corporate governance efforts. As an integral part of corporate governance, information security must be aligned with the governance processes in place to oversee other critical functions within the organization. Turel and Bart [12] stated that in the years directly before their study that the involvement of boards of directors in IT matters had continued to increase to the point that their study was explicitly focused the antecedents and consequences of boardlevel IT governance.

According to Nazareth and Choi, [14] managing information security risks is both challenging and critically important particularly in light of the increasing frequency, rapid evolution, and severity of threats to organizations. Galdies [15] noted that such threats to organizations' information security stem from both internal and external actors and both unintentional and intentional actions on these actors parts. In practice, such threats may manifest as technical failures, system vulnerabilities, human error, fraud, and external events among others [15].

While research links effective leadership to decreased systemic risks, the literature also provides numerous definitions of leadership [32]. The questions that engaged the researcher were first "Wwhat type of leadership was most effective in the context of information security risk management (ISRM)?"; Second, "How did the inter-relationships between information technology leadership, information security governance impact on organizational information security risk management?

\section{Literature Review}

To avoid the need to address a multiplicity of definitions of leadership, while still being able to capture the perspectives of a full range of leadership styles, the theoretical framework was chosen to underpin the present study was Bass \& Avolio's Full Range Leadership Theory [11]. This theory is well supported and has been well validated [4]. There were additional reasons for choosing the FRLT as well. The first was that there was good empirical support for the validity of the FRLT in the context of IT. The second was that previous scholarship had found that CIOs were increasingly found at the board-level of organizations by the late 1990s and that the interactions of CIOs with the rest of top management was stronger in organizations who exhibited transformational IT vision[23].

The full-range leadership model instantiates the FRLT, and the present study utilized the Multifactor Leadership Questionnaire (MLQ-5X) which is the most recent version of the instrument associated with the model. The MLQ was explicitly designed by Avolio \& Bass[16] to assess a full range of leadership styles. The MLQ utilizes nine scales to measure three overarching leadership styles: transformational, transactional and passive-avoidant. It also provides two scales that measure the actual outcomes of leadership. 
There is a definite need for rigorous research on the effects of leadership on effective information security risk management in organizations. The senior leaders create the organization-wide culture of safety and business competencies in the organization. IT managers assist in the implementation of security programs and monitor information security management assurance in the organizations. Scholars have noted that effective IT leadership leads to superior outcomes for organizational IS risk management [1] [2]. The actual execution of IS risk management is the domain of the line managers in an organization who execute the vision and policies provided by IT leadership.

This literature review commences with discussions of IT leadership in the analytical context of the FRLT and IS risk management. Within IT leadership, transformational, transactional, and laissez-faire leadership styles are evaluated. The information security risk management portion of the literature review provides context on the interrelationships between policy, management, and implementation. Table 1 provides a summary of the three FRLT leadership styles.

\begin{tabular}{|c|c|c|c|}
\hline $\begin{array}{cc}\text { Basis } & \text { for } \\
\text { Comparison } & \end{array}$ & $\begin{array}{l}\text { Transactional } \\
\text { Leadership }\end{array}$ & $\begin{array}{l}\text { Transformation } \\
\text { al Leadership }\end{array}$ & $\begin{array}{l}\text { Passive-Avoidant } \\
\text { Leadership }\end{array}$ \\
\hline Meaning & $\begin{array}{l}\text { A leadership style } \\
\text { that employs rewards } \\
\text { and punishments for } \\
\text { motivating followers } \\
\text { is Transactional } \\
\text { Leadership. }\end{array}$ & \begin{tabular}{l}
\multicolumn{1}{c}{ A leadership } \\
style in which the \\
leader employs \\
charisma and \\
enthusiasm to \\
inspire \\
followers his \\
Transformational \\
Leadership.
\end{tabular} & $\begin{array}{l}\text { A leadership style that } \\
\text { vacillates and allows } \\
\text { subordinates room to operate } \\
\text { without interference is } \\
\text { Passive-avoidant }\end{array}$ \\
\hline Concept & \begin{tabular}{lr}
\multicolumn{1}{c}{ Leader } & \\
emphasizes & his \\
relationship & with \\
followers. &
\end{tabular} & $\begin{array}{l}\text { Leader } \\
\text { emphasizes the } \\
\text { values, ideals, } \\
\text { morals, and needs } \\
\text { of the followers. }\end{array}$ & $\begin{array}{l}\text { The leader emphasizes } \\
\text { freedom and skills. }\end{array}$ \\
\hline Nature & Reactive & Proactive & Consultative \\
\hline Best suited for & $\begin{array}{l}\text { Settled } \\
\text { Environment }\end{array}$ & $\begin{array}{r}\text { Turbulent } \\
\text { Environment }\end{array}$ & $\begin{array}{c}\text { Poorly defined roles. } \\
\text { Feedback and consultation }\end{array}$ \\
\hline Works for & $\begin{array}{l}\quad \text { Developing } \\
\text { existing } \\
\text { organizational } \\
\text { culture. }\end{array}$ & $\begin{array}{l}\text { Changing the } \\
\text { existing } \\
\text { organizational } \\
\text { culture. }\end{array}$ & Independent and carefree. \\
\hline Style & Bureaucratic & Charismatic & Highly skilled \\
\hline $\begin{array}{l}\text { How many } \\
\text { leaders are there } \\
\text { in a group? }\end{array}$ & Only one & More than One & One to Many \\
\hline Focused on & $\begin{array}{l}\text { Planning and } \\
\text { Execution }\end{array}$ & Innovation & Skills and motivation \\
\hline $\begin{array}{l}\text { Motivational } \\
\text { tool }\end{array}$ & $\begin{array}{l}\text { Attracting } \\
\text { followers by putting } \\
\text { their own self- } \\
\text { interest in the first } \\
\text { place. }\end{array}$ & \begin{tabular}{l}
\multicolumn{2}{c}{ Stimulating } \\
followers $\quad$ by \\
setting group \\
$\begin{array}{l}\text { interest as a } \\
\text { priority. }\end{array}$
\end{tabular} & $\begin{array}{l}\text { High level and intrinsic } \\
\text { motivation }\end{array}$ \\
\hline
\end{tabular}


Note. Comparison of the leadership styles. Key differences between transactional, transformation and passive-avoidant leadership. By S. Surbhi 2015. https://keydifferences.com/wp- content/uploads/2015/07/Transactional-VsTransformational-leadership3.jpg. Adapted with permission.

Table 1. FRLT Leadership Styles

\section{IT Leadership and the FRLT}

Thite's seminal empirical research[24] strongly linked transformational and transactional leadership to effective IT leadership practice. Scholars have found that the FRLT has strong explanatory power. The three key leadership behaviors captured by the FLRT are discussed in detail in the three following sections. $\quad$ Figure 1 depicts the spectrum of leadership styles with their associated behavioral dimensions.

Passive avoidant/laissez-faire leadership. Passive-avoidant leadership is a nontransactional laissezfaire leadership style characterized by some scholars as a non-leadership style. Scholars often define passive-avoidant leadership as leadership that "abdicates responsibilities avoid making decisions" . Indeed, scholars such as Shao, Feng, and Liu[17] equated passive-avoidant leadership with a refusal to lead. Key characteristics of passive-avoidant leaders are their propensity to vacillate and their desire to avoid making decisions, particularly critical or high-priority decisions. Often viewed as uninvolved, passive-avoidant leaders are frequently withdrawn and uncaring or unconcerned about the goals of the project or organization to which they are associated[26].

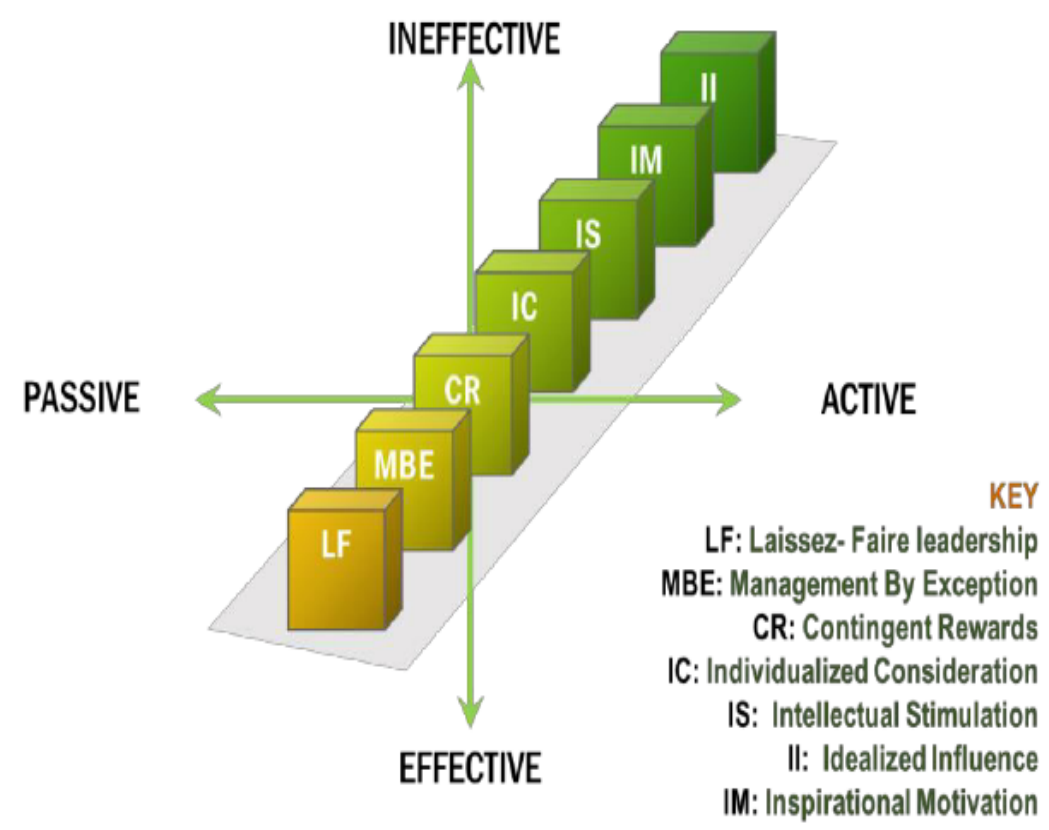

Figure 1. Schematic representation of FRLT spectrum.

By V. Renjith 2015.

https://www.researchgate.net/figure/Schematic-Representation-of-Full-Range-

Leadership_fig4_277138454. Permission forthcoming. 
One notable consequence of passive-avoidant behavior is that the leaders that exhibit such behaviors negatively impact the cohesion of the teams they lead[26]. In addition to the negative characteristics that earlier scholars have ascribed to passive-avoidant leaders, Salter, Harris, and McCormack[18] found that there was also a negative correlation between moral reasoning and passive-avoidant leadership. Passive-avoidant leaders do not convey a strong moral identity to their followers. Without the ability to convey a strong moral dimension in communications with followers, a key facet in the process of inspiring and influencing followers is lost. Avolio [3] noted that FRLM represents a spectrum of behaviors by leaders and that what is of note is how often a leader exhibits a given behavior. Thus, effective leaders exhibit passive-avoidant (i.e., laissez-faire) leadership behaviors infrequently or in exceptional circumstances. Chaudry and Javed [19] stated, based on their research, that such exceptional circumstances did exist when passive-avoidant leadership was appropriate. Passiveavoidant leadership was found to yield positive results in circumstances in which team members had an intrinsic motivation [19]. Chaudry and Javed [19] stated that passive-avoidant leadership could be appropriate where team members were highly experienced in their fields and well-motivated. Chaudry and Javed [19] provided the specific example of scientists as highly experienced and well-motivated professionals.

Transactional leadership. Transactional leadership is a style of leadership that focuses on organization and supervision in pursuit of group performance[27]. Scholars sometimes also refer to this style of leadership as managerial leadership[27]. The three distinct factors that characterize variants of the transactional leadership style are (a) passive management by exception (MBE), (b) active MBE, and (c) contingent reward (see Table 2). The transactional leadership style concentrates on the exchanges between leaders and subordinates in the organization[22]. Burns [28] initially proposed the transactional leadership theory basing it on the idea that an employee receives a reward for their acceptance of authority within the organization. Penn [13] defined transactional leadership as a contract between a leader and followers. Such implicit contracts or agreements are based on performance commitments allowing each party to receive something of value. The transactional leadership approach rewards compliance and punishes nonperformance or noncompliance. Leaders are motivated to achieve the business's goals and objectives, and they are empowered to train, evaluate, and reward subordinates in pursuit of the organization's objectives.

Leaders who follow the transactional approach rely on establishing parameters, guidelines, rules, and standards for performance as well as on extrinsic-based systems of reward and punishment [29]. A manager implementing the transactional leadership style is a leader who monitors his or her followers' work to ensure minimal deviations in work practices from those established for the given task. Such leaders are responsive to changes in circumstance and focus on task completion, not on the people they lead[29]. Transformational leadership. Downton[20] first introduced the notion of transformational leadership; however, scholarly interest in transformational leadership commenced with Burns[28]. According to Zhu et al. [21] Transformational leadership theory is one of the most commonly used leadership theories in organizational management.

Transformational leadership is a style of leadership that is more active than the transactional leadership style and which places a focus on the norms and values of followers [5]. Such leadership aims to encourage followers to move beyond their self-interest and move towards a common shared purpose. Transformational leadership represents leadership behaviors on the right-hand side of the FRLT leadership spectrum [16]. Leadership on the right-hand side of the spectrum represents the most effective leadership behaviors identified by Avolio and Bass [16].

Four factors underpin the transformational leadership style. These are: (a) individual consideration (IC) or caring, (b) intellectual stimulation (IS) or thinking, (c) inspirational motivation (IM) or charming, and (d) idealized influence (II) or influencing (Table 4). Table 24 directly below summarizes the four components of transformational leadership. 


\begin{tabular}{|c|c|}
\hline TFL Components & Elements \\
\hline $\begin{array}{l}\text { Idealized Influence } \\
\text { (II) }\end{array}$ & $\begin{array}{l}\text { Being a role model that is highly regarded, valued, trusted, and } \\
\text { deserving emulation }\end{array}$ \\
\hline $\begin{array}{c}\text { Inspiration } \\
\text { Motivation (IM) }\end{array}$ & $\begin{array}{l}\text { Encouraging enthusiasm in others through challenge and } \\
\text { instilling a sense of significance while promoting cohesion, } \\
\text { harmony, and confidence }\end{array}$ \\
\hline $\begin{array}{c}\text { Intellectual } \\
\text { Stimulation (IS) }\end{array}$ & $\begin{array}{l}\text { Kindling creativity and inventiveness by encouraging novel } \\
\text { ideas, questioning, and thinking outside the box }\end{array}$ \\
\hline $\begin{array}{c}\text { Individualized } \\
\text { Consideration (IC) }\end{array}$ & $\begin{array}{l}\text { Paying particular attention to the individual needs of each } \\
\text { follower }\end{array}$ \\
\hline $\begin{array}{c}\text { Source: Bedi et al. [5]. A meta-analytic review of ethical leadership outcomes and } \\
\text { moderators, permission forthcoming. }\end{array}$
\end{tabular}

Table 2. Transformational Leadership Components and Their Elements

\section{Theory}

The theoretical orientation of the present study rests on the full range leadership theory (FLRT). Bass and Avolio[22] developed the FRLT based on work by Burns [28] who first conceived of the idea of transformational authority. Bass and Avolio [22] used the notion of transformational authority to develop their concept of transformational leadership. In terms of the FRLT,

"There are three types of leadership behaviors, represented by nine distinct factors. These are Transformational (idealized influence attributed to charisma, idealized influence behavior attributed to beliefs and values, inspirational motivation, intellectual stimulation, individualized consideration). Transactional (contingent rewards, management-by-exception passive, management-by-exception). Nontransactional laissez-faire.” ( [4], p. 7)

The full-range leadership model (FLRM) instantiates the FLRT. Avolio [4] noted that it is fundamental to the FLRM that "...every leader displays each style to some degree." (p. 67) The FRLM does not provide a continuum of behaviors that go from bad to good. Instead, the FRLM represents a continuum that progresses from less to more effective leadership behaviors, and that effectiveness is dependent on circumstances. A full-range leader chooses the leadership style that best suits the circumstances [4].

Like other forms of leadership, IT leadership can be characterized based on the styles leaders use when interacting with subordinates. The three leadership styles examined in the present study are the transformational, transactional and passive-avoidant as understood by Bass and Avolio's FRLT [16]. Scholars have identified many leadership styles; however, not all are appropriate in any given context or industry. The present study utilizes the FRLT as empirical research has shown its applicability to IT leadership.

Thite [24] conducted a seminal study on IT leadership styles and found that no one leadership style was suitable in all situations. Instead, Thite discovered that an amalgamation of behaviors blending transformational and technical leadership styles enhanced transactional leadership effectiveness. This combination of leadership styles led to superior outcomes characterized by high rates of project success. Thite's research provided empirical validation that transformational and transactional leadership theories are a good fit with leadership in ICT. Furthermore, Thite's study provided support for Bass and Avolio's [4] work on transformational leadership and the development and use of the FRLT within the domain of ICT management.

IT leadership is often represented at board level by a Chief Information Officer (CIO). Armstrong and Sambamurthy [23], studying the phenomenon of the arrival of CIO's in top management teams, 
found that CIO interaction with top management was stronger in firms with transformational IT vision. Table 3 below summarizes the functions of governance versus management.

\begin{tabular}{|l|l|}
\hline Governance & Management \\
\hline Oversight & Implementation \\
\hline Authorizes decision rights & Authorized to make decisions \\
\hline Enact policy & Enforce policy \\
\hline Accountability & Responsibility \\
\hline $\begin{array}{l}\text { Strategic planning } \\
\text { Resource allocation }\end{array}$ & Project planning \\
\hline $\begin{array}{l}\text { Note: From } \\
\text { https://spaces.at.internet2.edu/display/2014infosecurityguide/Information+Security+Governanc } \\
\text { e, permission forthcoming. }\end{array}$ \\
\hline
\end{tabular}

Table 3. Responsibilities of Governance Versus Management

\section{Methodology}

The present study sought to explore human conduct related to IT leadership style on IS risk management. Specifically, the study tested the statistical significance of the associations between IT leadership styles (i.e., transactional, transformational, and passive-avoidant) in U.S. organizations' use of an IS risk management framework.

This study used a deductive framework for the variables and research questions based on theory. This study sought to determine the nature of the relationship between the independent and the mediating variables [9] and then tested the influence of those variables on the dependent variable. The design examined and provided results that contributed to the existing literature on IT leadership and its impact on IS risk management.

\section{Data Analysis and Results}

Table 4 presents the descriptive statistics from the MLQ Rater Form to determine leadership style. The transformational leadership style had a high average mean of 4.01 rated on a scale of 1 to 5 and a standard deviation of 0.86 . These values indicated that this was the most highly exhibited leadership style. The transactional leadership style yielded a mean score of 3.73 measured on a scale of 1 to 5 . The scores indicated that many of the respondents utilized this leadership style because of its goal setting and rewards system. Few participants exhibited the passive-avoidant leadership style. 


\begin{tabular}{cllllll}
\hline Variable & $M$ & $S D$ & Min. & Max. & MeMed. & $\alpha$ \\
\hline $\begin{array}{c}\text { Transforma- } \\
\text { tional Scale } \\
\text { Transactional }\end{array}$ & 4.01 & 0.86 & 1 & 5 & 4.20 & 0.887 \\
$\begin{array}{c}\text { Leadership } \\
\quad \text { Passive- }\end{array}$ & 3.73 & 0.98 & 1 & 5 & 4.00 & 0.691 \\
$\begin{array}{c}\text { Avoidant } \\
\text { Leadership }\end{array}$ & 2.59 & 1.36 & 1 & 5 & 2.50 & 0.837 \\
\hline
\end{tabular}

Note. $N=250$

Table 4. Descriptive Statistics for MLQ Rater Form Leaders Style

To what extent are IT leadership styles individually related to IS risk management in U.S. organizations? This research question was answered by testing the following two hypotheses:

H01: There is no independent, statistically significant relationships between IT leadership styles and IS risk management in U.S. organizations.

Ha1: There is an independent, statistically significant relationships between IT leadership styles and IS risk management in U.S. organizations.

This set of hypotheses was also tested using a Pearson coefficient correlation test. The results of this test are presented in Table 5. Table 5 shows a strong, positive correlation between IT leadership style and IT risk management. This relationship was statistically significant $(r=.601, n=250, p=.000)$. Table 5 also shows a moderately strong relationship between IS governance and IT risk management $(\mathrm{r}$ $=0.694, \mathrm{p}=<.01)$. These findings demonstrate that the individual correlations between the variables were statistically significant at the bivariate level. The results indicated that the null hypothesis for Subquestion 1 could be rejected. The individual relationships between IT leadership, IS governance and IS risk management were all statistically significant.

\begin{tabular}{|c|c|c|c|c|}
\hline Statistic & & $\begin{array}{l}\text { SMEAN (IT } \\
\text { Lead) }\end{array}$ & $\begin{array}{l}\text { SMEAN (IS } \\
\text { Gov) }\end{array}$ & $\begin{array}{l}\text { SMEAN (IT } \\
\text { Risk) }\end{array}$ \\
\hline SMEAN (IT & $\begin{array}{r}\text { Pearson } \\
\text { Correlation }\end{array}$ & 1 & $.698^{* *}$ & $.601^{* *}$ \\
\hline Lead) & Sig.(2tailed) & & .000 & .000 \\
\hline SMEAN (IS & $\begin{array}{r}\text { Pearson } \\
\text { Correlation }\end{array}$ & $.698^{* *}$ & 1 & $.694^{* *}$ \\
\hline Gov) & Sig.(2talied) & .000 & & .000 \\
\hline SMEAN(IS & $\begin{array}{r}\text { Pearson } \\
\text { Correlation }\end{array}$ & $.601^{* *}$ & $.694^{* *}$ & 1 \\
\hline Risk) & Sig.(2talied) & .000 & .000 & \\
\hline
\end{tabular}

**. Correlation is significant at the 0.01 level (2-tailed). b. Listwise $\mathrm{N}=250$

Table 5. Pearson Coefficient Correlation Test

\section{Summary and Discussion}

The present study was significant as IT leadership, IS governance and IS risk management constitute crucial topics for modern organizations [8]. Moreover, scholars have noted that organizations are 
challenged by the lack of knowledge related to the role that IT leadership plays in improving IS risk management in organizations [7][30].

The present study also found that there are independent, statistically significant relationships between IT leadership styles and ISRM in U.S. organizations. Based on the previously extended scholarly literature on IT leadership, the relationship between IT leadership style and ISRM was not a surprising finding, as ISRM is a sub-component of the overall set of responsibilities for which IT leadership is responsible

\section{Conclusion}

The theoretical scholarly literature on leadership strongly linked effective leadership, whether in the field of IT or more generally, with the style of leadership. The FRLT, as the single most popular explanatory theory of leadership in the last two decades, was particularly appropriate for application, as it specifically provided a spectrum of leadership types, identified from least to most effective[16]. In light of the extremely rapid change in the field of IT and the sub-field of ISRM, it was at minimum plausible that the most effective leadership styles would be most applicable to IT leadership. Thus, all three, previous scholarly research, the practitioner literature and the present study's findings, suggested that the FRLT theoretical framework was an appropriate analytical choice. Indeed, it proved serendipitous as during the years, in which the paper was being written, the increasing emphasis on proactive IS security policies made the FRLT's transformational leadership style an increasingly strong choice as a style related to superior ISRM outcomes.

A 2016 survey of U.S. IS security professionals noted that full application of frameworks, such as the NIST SP800-543, while optimal, can be very resource intensive[31]. Indeed, the professionals surveyed noted that many organizations only implemented parts of the frameworks they deployed due to cost considerations[31].

\section{References}

[1] Adesemowo, A. K., Von Solms, R., \& Botha, R. A. (2016). Safeguarding information as an asset: Do we need a redefinition in the knowledge economy and beyond? South African Journal of Information Management, 18(1), 1-12. https://doi.org/10.4102/sajim.v18i1.706

[2] Agarwal, R. N. (2017). Cases in leadership. India: Sage.

[3] Avolio, B. J. (1999). Full leadership development: Building the vital forces in organizations. Thousand Oaks, CA: Sage.

[4] Avolio, B. J. (2011). Full range leadership development. Thousand Oaks, CA: Sage. https://doi.org/10.4135/9781483349107

[5] Bedi, A., Alpaslan, C. M., \& Green, S. (2015). A meta-analytic review of ethical leadership outcomes and moderators. Journal of Business Ethics, 139(3), 517-536.https://doi.org/10.1007/s10551015-2625-1

[6] Knorst, A. M., Vanti, A. A., Andrade, R. A. E., \& Johann, S. L. (2011). Aligning information security with the image of the organization and prioritization based on fuzzy logic for the industrial automation sector. Journal of Information Systems and Technology Management,8(3), 555-580. https://doi.org/10.4301/S1807-17752011000300003

[7] Landis, E. A., Hill, D., \& Harvey, M. R. (2014). A synthesis of leadership theories and styles. Journal of Management Policy and Practice, 15, 97-100. Retrieved from http://www.nabusinesspress.com/jmppopen.html 
[8] McFadzean, E., Ezingeard, J. N., \& Birchall, D. (2011). Information assurance and corporate strategy: A Delphi study of choices, challenges, and developments for the future. Information Systems Management, 28(2), 102-129. https://doi.org/10.1080/10580530.2011.562127

[9] Gbenle, I. T. (2013). An examination of the relationship between information technology governance (ITG) and leadership in organizations (Doctoral dissertation). Capella University, Minneapolis, MN.

[10] Bobbert, Y., \& Mulder, H. (2015, December). Governance practices and critical success factors suitable for business information security. In 2015 International Conference on Computational Intelligence and Communication Networks (pp. 1097-1104). Washington, DC: IEEE Computer Societyhttps://doi.org/10.1109/CICN.2015.216

[11] Von Solms, S. H., \& von Solms, R. (2009). Information security governance. New York, NY: Springer. https://doi.org/10.1007/978-0-387-79984-1

[12] Turel, O., \& Bart, C. (2014). Board-level IT governance and organizational performance. European Journal of Information Systems, 23(2), 223-239. https://doi.org/10.1057/ejis.2012.61

[13] Penn, A. (2015). Leadership theory simplified. Retrieved from https://www.uaex.edu/publications/PDF/FSPSD200.pdf

[14] Nazareth, D. L., \& Choi, J. (2015). A system dynamics model for information security management. Information \& Management, 52(1), 123-134. https://doi.org/10.1016/j.im.2014.10.009

[15] Galdies, P. (2014). The insider threat to data assets. Journal of Direct, Data and Digital Marketing Practice, 15(3), 197-200. https://doi.org/10.1057/dddmp.2014.2

[16] Avolio, B. J., \& Bass, B. M. (2004). MLQ multifactor leadership questionnaire: Manual and sample set (3rd ed.). Redwood City, CA: Mind Garden.

[17] Shao, Z., Feng, Y., \& Liu, L. (2012). The mediating effect of organizational culture and knowledge sharing on transformational leadership and enterprise resource planning systems success: An empirical study in China. Computers in Human Behavior, 28(6), 2400-2413. https://doi.org/10.1016/j.chb.2012.07.011

[18] Salter, C., Harris, M., \& McCormack, J. (2014). Bass \& Avolio's full range leadership model and moral development. Retrieved from https://www.gcasa.com/conferences/milan/paper/McCormack.pdf

[19] Chaudry, A. Q., \& Javed, H. (2012). Impact of transactional and laissez-faire leadership style on motivation. International Journal of Business and Social Science, 3, 258-264. Retrieved from http://www.ijbssnet.com/journals/Vol_3_No_7_April_2012/28.pdf

[20] Downton, J. V. (1973). Rebel leadership: Commitment and charisma in the revolutionary process. Florence, MA: Free Press.

[21] Zhu, W., Sosik, J. J., Riggio, R. E., \& Yang, B. (2012). Relationships between transformational and active transactional leadership and followers' organizational identification: The role of psychological empowerment. Journal of Behavioral and Applied Management, 13, 186-212. Retrieved from https://jbam.scholasticahq.com/

[22] Bass, B. M., \& Avolio, B. J. (1997). Full range leadership development: Manual for the Multifactor Leadership Questionnaire (pp. 43-44). Palo Alto, CA: Mind Garden.

[23] Armstrong, C. P., \& Sambamurthy, V. (1999). Information technology assimilation in firms: The influence of senior leadership and it infrastructures. Information Systems Research, 10(4), 304327. https://doi.org/10.1287/isre.10.4.304

[24] Thite, M. (2000). Leadership styles in information technology projects. International Journal of Project Management, 18(4), 235-241. https://doi.org/10.1016/S0263-7863(99)00021-6

[25] Robbins, S. P., Judge, T. A., \& Sanghi, S. (2007). Organizational Behavior (12th ed.). India: Pearson.

[26] Hinkin, T. R., \& Schriesheim, C. A. (2008). A theoretical and empirical examination of the transactional and non-leadership dimensions of the Multifactor Leadership Questionnaire (MLQ). The Leadership Quarterly, 19(5), 501-513. https://doi.org/10.1016/j.leaqua.2008.07.001 
[27] Odumeru, J. A., \& Ifeanyi, G. O. (2013). Transformational vs. transactional leadership theories: Evidence in literature. International Review of Management and Business Research, 2, 355361. Retrieved from http://www.irmbrjournal.com/

[28] Burns, J. M. (1978). Leadership. New York, NY: Harper \& Row.

[29] Dartey-Baah, K. (2015). Resilient leadership: A transformational-transactional leadership mix. Journal of Global Responsibility, 6(1), 99-112. https://doi.org/10.1108/JGR-07-2014-0026

[30] Williams, S. P., Hardy, C. A., \& Holgate, J. A. (2013). Information security governance practices in critical infrastructure organizations: A socio-technical and institutional logic perspective. Electronic Markets, 23(4), 341-354.https://doi.org/10.1007/s12525-013-0137-3

[31] Dimension Research. (2016, March 2016). Trends in security framework adoption: A survey of IT and security professionals. Retrieved from https://static.tenable.com/marketing/tenable-csfreport.pdf

[32] Antonakis, J., \& Day, D. V. (Eds.). (2017). The nature of leadership (2nd ed.). Los Angeles, CA: Sage. 